\title{
INFLUENCE OF INFLATIONARY TAX ON THE REGIONAL ECONOMY OF GEORGIA AND THE NATIONAL BANK'S MONETARY POLICY
}

\author{
Vazha Verulidze, PhD in Economics, Professor \\ Faculty of Economics and Business, Batumi Shota Rustaveli State University
}

\begin{abstract}
Georgian economy is facing many challenges, including the high degree dependency of the consumer market on the import and inflation caused by the depreciation of the national currency.

Such situation has become permanent and has acquired the function of hidden tax burden, which significantly delays the development of the real economic sector of the region.

The aim of the research is to identify the influence of inflationary tax on the regional economy and their connection with monetary policy, to analyse the inflationary targeting mechanism, to identify the specifics of anti-inflation regulation and the role of the National Bank in the process of price stabilization.

Theoretical and empirical methods used in the article reveal that correlation between national currency depreciation against USD and inflation has established. The article highlighted that despite the monetary policy of the National Bank being implemented in the mode of inflation targeting and undergoing in the terms of a floating exchange rate, the inflationary pressures caused by the depreciation of the national currency continues to be, particularly, on the goods of the primary consumption. Bloomberg Electronic Trading System in order to determine the exchange rate doesn't not function properly in the country.

To ensure sustainable development of the economy, the National Bank should considerably improve the mechanism of exchange rate determination through the Bloomberg Electronic Trading System, and in order to reduce dependency on imports, it is crucial to elaborate mechanisms to develop and stimulate the production process based on the local resources.
\end{abstract}

Key words: regional economy, Exchange rate, inflation, Bloomberg Trading System. JEL code: E31, E58.

\section{Introduction}

This paper discusses inflation caused by default of the national currency exchange rate on condition of the open economy. This process itself is stipulated by the dependence of the inner market on the import. Research of this phenomenon has been significant for Georgia due to the current processes in regional economy that have been observed during the last 10 years and their results. Merely, it confirms that macroeconomic stability has not been maintained with the help of the economical mechanisms been applied so far. Slowed down economic development is obvious and reformation of the regions is not performed. An increase in the primary costs of local production and realization expenses has become of irrevocable nature. For instance, in 2017, compared to 2013, the national currency was devalued 1.55 times while the Consumer Price Index increased by 1.2 times and the total cost of production and realization of products increased by 1.63 times.

The aim of the research is to determine the main causes of the unsTable macroeconomic environment that delays the development of the country's regional economy.

In the terms of inflation, the NBG is limited to a change of the refinancing rate and to the interventions carried out in the case of imbalance between the demand and supply of the currency market as well as to direct participation in the process of trading.

With the increase of the refinancing rate, NBG withdraws the surplus money from the economy, however, it doesn't achieve the price stability as inflation is stipulated not by the excess of money, but a fall in the exchange rate of the national currency in relation to foreign currency. For a fragile economy like Georgia's, leaving of a separate segment of the market including the currency market in the self-regulation mode seriously damages macroeconomic stability of the country. The 2008 global economic crisis has actually confirmed the necessity of regulating the economy in order to prevent the crises. 
Inflation caused by the changes in the current exchange rate has become significant since the example of Georgia over the years proved that the approach of targeting inflation in the regime of monetary policy applied worldwide didn't ensure price stabilization. It has also been confirmed that the Bloomberg Electronic Trading System introduced in many developed or developing countries has not been successful in all economic conjunctures.

The main challenge of the NBG is the essential revision of the monetary policy and development of the effective anti-inflation policy.

To minimize the negative external trade balance and inflationary pressure, it is necessary to ensure the legislative regulation to stimulate local production.

In these conditions, it is especially important to ensure effective use of the resource potential of the regional economy in order to improve export-import imbalance.

\section{Results}

For regional economics of Georgia, price increases on the product and service, caused by inflation, which occurs in the form of hidden inflationary tax, is the same burden for economic agents budgets as tax burden, it is unpredicTable in most cases and hinders taking preliminary preventive measures. Inflationary tax is additional expense, which should be paid by the economic agents under the conditions of inflation that weakens the regional economics of the country even more. Therefore, the subject of current analysis is such widespread economic phenomenon in Georgia as the burden of inflation, caused by the change of exchange rate.

Regional economy, for its part, is the weakest link of the national economy; as "72\% of the total business sector turnover comes from Tbilisi-based companies, being 2.5 times larger than the turnover of the companies operating in all other regions of Georgia. Tbilisi companies have created $63 \%$ of all jobs in Georgia." (Decree of the Government of Georgia, 2018).

The increase of the raw material prices due to inflation and the increase in the excise rate in 2017 have resulted in rise of total expenses for production and sales (Table 1 ) that is observed annually in all regions (Entrepreneurship in Georgia, 2018). For example, in the autonomous republic of Adjara, this indicator increased by 1.94 times in 2017 compared with 2013.

The price rise, caused by the increase of tax rate, especially on the consumer goods, took place in 2017 in Georgia, because since the $1^{\text {st }}$ of January 2017 the excise duty has significantly increased on the gas of oil products and on natural gas as well as on oil products and oil distillates (Tax Code of Georgia, 2017). This was carried out in parallel to profit tax reform, which meant to exempt from the profit tax in case of profit reinvestment by the economic agents and the possibility to leave the above-mentioned amount with them or in the economics. However, finally it led to the situation that more money came out from the economics by increasing the excise duty, than it was left from the exemption of profit tax in the economics. 
Total expenses for production and sales By region, $\mathrm{mln}$ GEL

\begin{tabular}{|l|l|l|l|l|l|}
\hline Region & $\mathbf{2 0 1 3}$ & $\mathbf{2 0 1 4}$ & $\mathbf{2 0 1 5}$ & $\mathbf{2 0 1 6}$ & $\mathbf{2 0 1 7}$ \\
\hline The city of Tbilisi & 29185.7 & 33407.6 & 38270.5 & 42710.9 & 47700.0 \\
\hline Abkhazeti AR & - & - & - & - & - \\
\hline Adjara AR & 2487.8 & 3209.6 & 3818.7 & 4499.7 & 4849.8 \\
\hline Guria & 182.1 & 220.1 & 292.5 & 387.1 & 399.7 \\
\hline Imereti & 1920.6 & 2252.4 & 2173.7 & 2634.1 & 3049.8 \\
\hline Kakheti & 824.6 & 978.3 & 992.7 & 985.6 & 1161.5 \\
\hline Mtskheta-Mtianeti & 539.2 & 615.3 & 638.2 & 636.2 & 808.1 \\
\hline $\begin{array}{l}\text { Racha-Lechkhumi and Kvemo } \\
\text { Svaneti }\end{array}$ & 35.4 & 30.2 & 42.3 & 55.4 & 61.8 \\
\hline Samegrelo-Zemo Svaneti & 1480.7 & 1575.6 & 1768.0 & 1965.9 & 2285.6 \\
\hline Samtskhe-Javakheti & 483.2 & 521.8 & 593.4 & 674.5 & 821.2 \\
\hline Kvemo Kartli & 2518.1 & 2570.0 & 3141.2 & 3315.7 & 3783.4 \\
\hline Shida Kartli & 840.0 & 940.7 & 1094.4 & 1215.7 & 1296.6 \\
\hline
\end{tabular}

Source: National Statistics Office of Georgia

In accordance with the analysis of statistical data of the National Bank of Georgia, it has been determined that in most cases, the changeability of the national currency did not have prerequisite and basis. For example, from the $25^{\text {th }}$ of August, 2017 till the $29^{\text {th }}$ of September 2017, the rate of national currency suddenly fell down with 7 points against the US Dollars and with 20 points - from $24^{\text {th }}$ of October till the 30 $30^{\text {th }}$ of November, 2017 (National Bank of Georgia, 2018). While there was No negative influence of seasonal factor on the national currency and the oil price had increased on the world market, that in fact should be the provocative factor of increasing the rate of national currency. The situation in the foreign exchange market had a negative impact on the consumer market in the conditions of the information vacuum. Therefore, on the $2^{\text {nd }}$ of November 2017, National Bank of Georgia released an explanation about the situation existing on the currency market that: „average and long-term factors, acting on the rate, are positive. Recently, especially in autumn, the change of GEL rate has caused the high expectation of depreciation. Despite the fact that this expectation does not have the real fundamental basis, it has still made an influence on the shortterm dynamics of GEL rate under the conditions of floating rate, increased the demand of foreign currency"( National Bank of Georgia, 2017).

We see that in dynamics the rate of the national currency in relation to the foreign currency is more and more falling down (Figure 1). The current situation in the Georgian foreign exchange market has proved that a large amplitude of fluctuations in the national currency is not connected by seasonal factors, nor by the expectation of society or nor external factors (for example, oil prices on the world market).

In such situation, there is a background to assume that in a developing country with a small economics like Georgia, problem can be to use the Bloomberg trading system in order to determine the exchange rate of the national currency. This assumption is also justified by the fact that the National Bank of Georgia, since the $5^{\text {th }}$ of January 2018, was forced to make changes in the rule of determining the rate, where it has been marked out that: in the manner existing till now, if in 
Bloomberg trading system on the interbank market the volume of the trade had not exceeded 3 million US Dollars, in calculation of the official rate of GEL the previous day deals also participated.

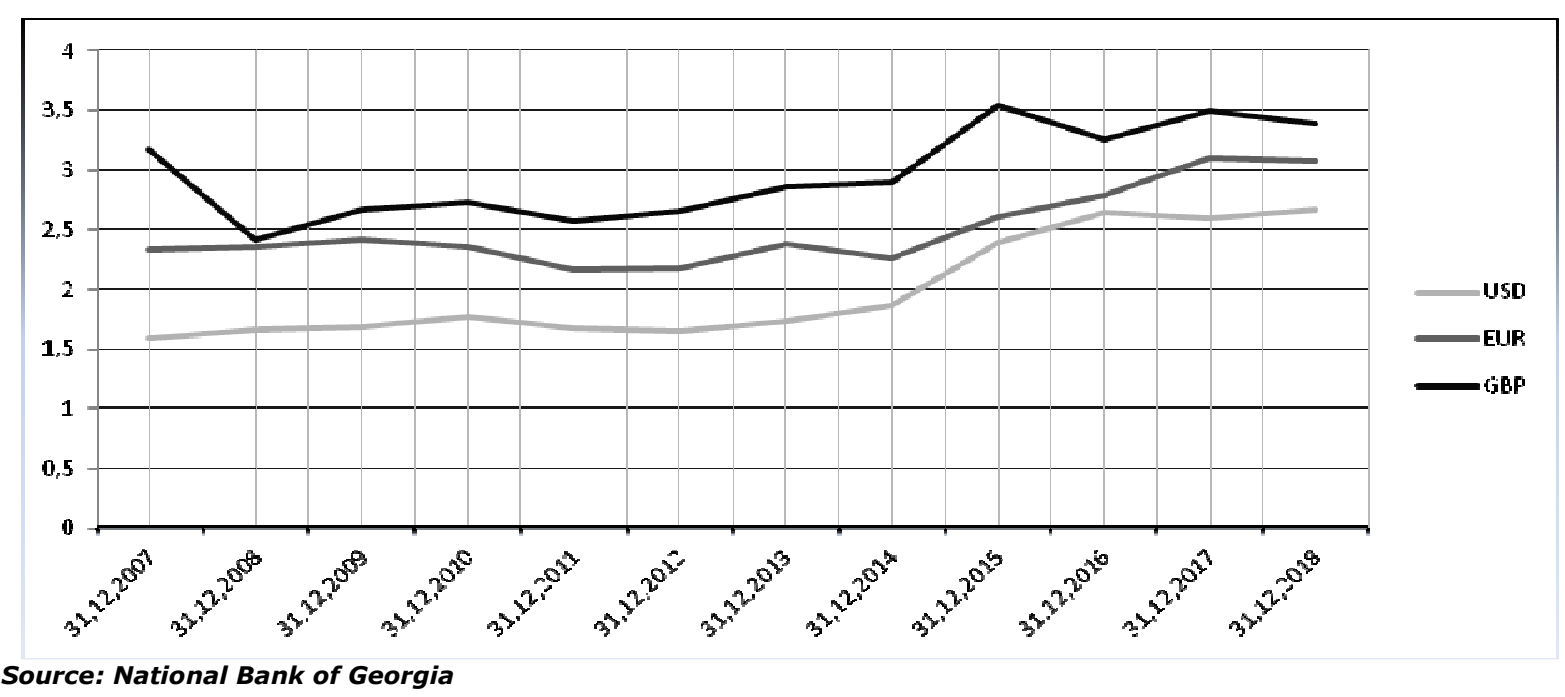

Fig. 1. Dynamics of the exchange rate of the national currency

That is why, there were rare cases when official and market rates were significantly different from each other, the reason of which was the low activity on the market on a concrete trading day. With the mentioned amendment, the above mentioned limit will be halved (till 1.5 million US dollars), as a result of it, official rate will be much closer to the market rate (National Bank of Georgia, 2018). This explanation of the national bank actually means that on interbank market, in case of small volume of trade, it may form such rate of GEL, which will be in conflict with the current processes in economics and it will provoke inflation. Importers react quickly on depreciation of GEL and increase the prices and this is reflected negatively on the activity of economic agents. In this case, the Bloomberg trading system needs to be improved because, this system only works correctly for large volumes of trading in the interbank market.

The National Bank of Georgia cannot manage to stop the inflationary pressure with monetary policy in short-term period, caused by depreciation of the national currency. Accordingly, to increase financial stability in long-term period, it uses the rate of monetary policy for the purpose of prevention of the expected inflation, which is now equal to $6.75 \%$ (National Bank of Georgia, 2008-2018). The tight money policy prevents providing the economics with the required money. Therefore, society tries to adapt under the conditions of inflation, when the consumer price index is increasing annually (National Statistics Office of Georgia, 2010-2018), (Figure 2).

The main challenge of the economy of Georgia is a high degree of dependence on the import, which increases sensitivity towards the changes of the exchange rate. According to the data of 2016 of the payment balance of Georgia, $15.1 \%$ of the import is hold by the investment product, $41.6 \%$ - the product of the intermediate consumption and $43.3 \%$ the product of consumer product (Balance of Payments of Georgia, 2016).

The negative consequences caused by inflation affect the regional economic agents, insofar as "Trade, repairs of motor vehicles and personal and household goods, transport and communication alongside construction sectors are the key drivers of growth in Tbilisi and AR Adjara" (Decree of the Government of Georgia, 2018). 


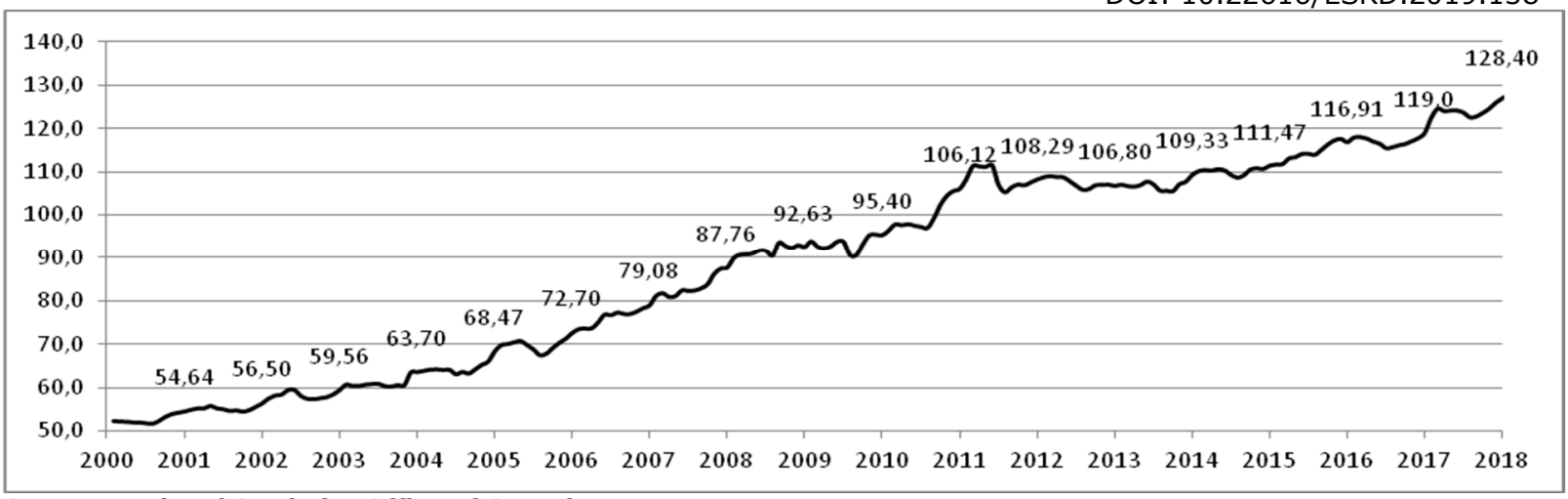

Source: National Statistics Office of Georgia

Fig. 2. Consumer Price Index (2010 average=100)

The problem is complicated by the fact that the choice of access on money resources for economic agents reduced by the undeveloped securities market, that creates the fertile soil to establish unfair rules of game by the bank sector, and due to inflation, they rose interest rates on loans. The author shares the opinion about the connection between the development of financial markets and economic growth, which was concluded by R. King and R. Levine. In particular, they noted that "there is strict and sustainable relationship between the level of the development of financial markets and long-run rate of the economic growth" (Danilov, Pivovarov, 2018).

For the sustainable development of regional economics of Georgia, financial stability of the trading partner countries has also great importance, because border regions mainly depend on the import. "Adjara AR, Guria and Samtskhe-Javakheti are the least industrialized Georgian territories. Share of industrial GVA in total GVA in those regions is meagre $8 \%, 6 \%$ and $5 \%$ respectively" (Decree of the Government of Georgia, 2018). Financial stability in these regions also associate with events in Turkey, where inflation has recently exceeded $15 \%$ (DAILY SABAH, 2018). In such situation, the depreciation of the national currency in Georgia will stimulate the import, and hinder weak local production.

In Georgia, it is empirically proven that, there is a similar correlation between the inflation and price rise as between the introduction of new taxes and price rise. Therefore, whether the price rise is stipulated by inflation or increase of tax burden, it has one and the same negative influence on the real economics of the country.

„As analysis shows, Georgia has two sectors in which brand products are already developed: tourism and agriculture" (Decree of the Government of Georgia, 2018). Agriculture is the field, the share of which in GDP has not increased for the last 10 years. The country is not able to provide its own population with agricultural products, but the government of Georgia has a vision in terms of regional development and thinks that "national, sectoral and regional development policies and strategies must be formulated with reference to the needs and development potentials of regions and territories, encompassing comprehensive territorial analyses and the differentiation of policy interventions and public investments in territorial terms" (Decree of the Government of Georgia, 2018).

Because of the dependence of the high degree on the import of the consumer market, the price rise in Georgia is mostly stipulated not by the existence of excess funds in the economy (the average rate of the monetization coefficient $\left(M_{2}\right)$ does not exceed 17.71), but by depreciation of national currency towards the foreign currency, in particular towards the US dollars. Economics of Georgia turned out to be flaccid and very fragile during the impact of such factor as the change of currency rate is. 


\section{Discussion}

The National Bank of Georgia implements the monetary policy in the targeting regime of inflation. This means that price stability is considered as the main goal of monetary policy, however results are not achieved yet "Despite the widely used targeting regime of inflation in modern conditions, the discussions about the adequacy of inflation targeting under the conditions of financial crisis as well as about its use in various countries are still going on" (Pestova, 2018).

According to the explanation of the National Bank of Georgia, the reason of such massive depreciation in the analysed period became the high expectation of depreciation in autumn and the influence of all other factors was evaluated only positively from its side. The explanation of such content of the national bank does not have the fundamental background because the past experience and analysis of statistical information makes clear that the expectation of depreciation in society did not begin in August-September but in December, because the increase of demand on the foreign currency was mainly caused in this period by the importers.

„In the case of emerging and transition economies, as the exchange rate exerts an influence on external and internal macro stability, clean floating is not a desirable option. Exchange rate depreciation may lead to inflation or negative balance sheet effects in financially dollarized/euroized economies. As a result, countries tend to adopt dirty floating, which assumes (in)direct manipulating fluctuations, although the exchange rate is not targeted per se" (Josifidis, Allegret, \& Pucar, 2011).

The current situation on the currency market of Georgia confirmed that the fluctuations with a large amplitude of the national currency, in most cases, are related neither to seasonal factor nor the expectation of society and the external factor (for example, oil price on the world market). That's why it is difficult and almost impossible to predict the burden inflationary tax in advance for the economic agents, which creates unbalanced economic environment in the country.

One difficulty involved in switching to inflation targeting is the introduction of a floating exchange rate regime, in which significant fluctuations in the national currency's exchange rate may have a negative effect on inflation dynamics. However, these fears are not always justified. Inflation targeting noticeably reduces exchange rate pass-through to inflation, thus causing fluctuations of the national currency's exchange rate to have only a slight effect on consumer prices. Moreover, international experience shows that an inflation targeting regime is compatible with a managed floating exchange rate regime (Kataranova, 2010). But, it should be noted that, the international experience, which permits, the compatibility of the targeting regime of inflation with floating exchange rate, failed in Georgia and the mentioned regime cannot slow down to increase the consumer prices.

Food inflation has a direct contemporaneous effect on total inflation because food comprises approximately $30 \%$ of the consumption basket. Higher food inflation implies higher relative prices of food items, and thereby higher total inflation. Indirectly, food inflation may affect inflation expectations (Gomez, Gonzalez, Melo, 2012). In Georgia, the increased price of the food products, is perceived with an extreme acuity, and it should unambiguously be said that it causes the inflationary expectations.

As the winner of Nobel memorial prize Joseph E. Stiglitz points out "it is awfully important planning the reforms and consequentiality of the rhythm for the development of economics. For example: if the market is opened very quickly for the competition (while strong financial institutions are formed), work places will be cancelled faster than new ones are created" (Stiglitz, 2012). As for reform planning and rhythm in Georgia, process started in the 90-ies of the last century and the result is 
that the market of the country is actually opened, but still local production is not ready to compete the import product. "Agriculture delivering $9 \%$ of GDP, but at the same time being the main occupation for more than a half of the country's population" (Decree of the Government of Georgia, 2018).

Chronic inflation ended in Brazil and Argentina after battling with it for long years. Assuming that the economic strategies to deal with inflation have been standardized and widely known, this paper focused on the political conditions that facilitate successful stabilization. It is argued that, if there is already an adequately designed disinflationary program at hand, political support from broad sections of the society is the most important factor for successful stabilization (Ozdemir, 2015). It should be noted that, in Georgia, proper use of public support and the resource of positive mood has not been made since the date of its moving to the market economy and the first reason of it is that, under the conditions of high confidence from the public, state had not fully had realized the scale of the reforms, to be implemented and the second reason is that when government formed its decision, public support had already become very weak. Accordingly, the reforms, started in the economics, are incomplete or the most important economic reforms have not begun yet.

The country needs systemic economic reforms, which at first will make the real sector of economics stronger, and then the market will be open for foreign companies and not on the contrary, which is taking place now.

Despite the current situation in the Georgian economy, there is still a possibility of its development. "There are segments of potential growth, of the goods and service in low-rate developing countries" (Kondrat'ev, 2018). In Georgia, processing sector of agricultural production can be considered as such segment, on which it is possible to increase the demand, because its primary raw materials will be ecologically clean agricultural products.

\section{Conclusion}

This study analysed the connection between the depreciation and inflation of the national currency, which in turn was stipulated by the high dependency of the country's consumer market of the country on the import. The results of the study prove that the depreciation of the national currency is not often caused by the fundamental economic factors. Therefore, it is unpredicTable and results in an increase in the prices of imported goods. The current situation is particularly severely reflected on the regional economy as it increases the cost of goods and services, and accordingly the prices, the prime costs of which have the component of the imported goods. The analysis revealed that the monetary policy of the NBG can not maintain the stability of the prices. According to the research outcomes, for the country with such a small economy like Georgia where the currency market turnover is also low, determination of the national currency rate through the Bloomberg Trading System is distinguished with its weaknesses and can not ensure the sustainability of the monetary market that causes inflation.

The results of the analysis enabled us to draw the following conclusions

1) Inflation is stipulated by the depreciation of the national currency rate and the high dependency of the domestic market on the imports. Therefore, for the sustainable development of the regional economy it is necessary to reduce the inflationary burden on economic agents and create various opportunities to develop production based on the local resources that would gradually reduce dependence on imports. For this purpose, it is necessary for the National Bank to change the currency exchange rate mechanism through the Bloomberg Electronic Trading System. Thus, that 
would eliminate the fluctuation of the national currency rate due to non-fundamental factors in the currency market and the stability of the currency market would be achieved.

2) To stimulate national production, differential legislative interventions are required according to regions that would ensure efficient use of existing resources. Excessive and unused resources of the most regions are represented in agriculture. To develop this sector, in the conditions of an open economy, tax privileges are to be imposed. Namely, the companies processing the agricultural products should be exempt from the VAT. It would facilitate development of the real sector of the country's economy.

\section{Bibliography}

1. Balance of Payments of Georgia (2016). p.12. Retrieved: https://www.nbg.gov.ge/uploads/publications/balanceofpayments/2015/bop_2016_eng.pdf. Access: 20.04.2018.

2. DAILY SABAH (2018). Turkey's Inflation Rate Hits 15.39 percent in June - Retrieved: https://www.dailysabah.com/economy/2018/07/03/turkeys-inflation-rate-hits-1539-percent-in-june. Access: 14.09.2018.

3. Danilov, Yu. A., Pivovarov, Danil. A. (2018). Financial Structure in Russia: Conclusions for State Policy. Issues of Economics. 2018, No 3, p. 31.

4. Decree of the Government of Georgia (2018). №1292, 11 June, Tbilisi, on the approval of the Regional Development Programme of Georgia for 2018-2021. Retrieved: http://www.mrdi.gov.ge/sites/default/files/20182021_regional_development_programme_of_georgia_unofficial_translation.pdf. Access: 05.09.2018.

5. Entrepreneurship in Georgia (2018). Statistical publication Retrieved: http://geostat.ge/cms/site_images/_files/georgian/Mewarmeoba \%20saqartveloshi \%202017.pdf. Access: 05.12.2018.

6. Gomez, M. I., Gonzalez, E. R., \& Melo, L. F. (2012). Forecasting Food Inflation in Developing Countries with Inflation Targeting Regimes. American Journal of Agricultural Economics, 94(1), pp.153-173. Retrieved from http://search.ebscohost.com/login.aspx?direct=true\&db=bsh\&AN=70250573\&site=ehost-live. Access: 11.10.2018.

7. Joseph E. Stiglitz (2012) Globalization and its discontents. Translation from English, Tbilisi 2012.

8. Josifidis, K., Allegret, J.-P., \&Pucar, E. B. (2011). Inflation Targeting and Exchange Rate Regimes in Serbia and Selected Transition Economies. Eastern European Economics, 49(4), pp. 88-105. Retrieved from http://search.ebscohost.com/login. aspx?direct=true\&db=bsh\&AN=66237930\&site=ehost-live. Access: 11.10.2018.

9. Kataranova, M. (2010). The Relationship Between the Exchange Rate and Inflation in Russia. Problems of Economic Transition, 53(3), pp. 45-68. Retrieved: https://doi.org/10.2753/PET1061-1991530303. Access: 02.10.2018.

10.Kondrat'ev, V. (2018.) New Globalization Phase: Key Elements and Perspectives. World Economy And International Relations. No 6, p. 8.

11. National Bank of Georgia (2008-2018). Committee decisions. Retrieved: https://www.nbg.gov.ge/index.php?m=554\&lng=eng. Access: 02.02.2019.

12. National Bank of Georgia (2017). Statement Of The National Bank Of Georgia, Regarding The Currency Rate Fluctuations Within The Foreign Exchange Market. Retrieved: https://www.nbg.gov.ge/index.php?m=340\&newsid=3223. Access: 11.04.2018.

13. National Bank of Georgia (2018). Official And Market Exchange Rates Of Lari. Retrieved: https://www.nbg.gov.ge/index.php?m=340\&newsid=3262. Access: 23.03.2018.

14. National Bank of Georgia (2018). Statistical Data. Exchange Rates. Retrieved: https://www.nbg.gov.ge/index.php?m=306\&lng=eng. Access: 02.02.2019.

15. National Bank of Georgia (2018).statistical data, external sector. Retrieved: https://www.nbg.gov.ge/index.php?m=306\&lng=eng. Access: 02.02.2019.

16. National Statistics Office of Georgia (2010-2018).external trade. Retrieved: http://geostat.ge/index.php?action=page\&p_id=134\&lang=eng. Access: 25.01.2019.

17. National Statistics Office of Georgia(2010-2018) consumer price index. Retrieved: http://geostat.ge/index.php?action=page\&p_id=128\&lang=eng. Access: 16.01.2019.

18. Ozemir, Y. (2015). Political Conditions for Successful Iinflation Stabilization: comparing Brazil and Argentina. Revista Brasileira de Política Internacional, 58(1), pp. 63-83. Retrieved: https://doi.org/10.1590/0034-7329201500104. Access: 02.10.2018.

19. Pestova, A.A. (2018). On the Effects of Monetary Policy in Russia: The role of the space of spanned shocks and the policy regime shifts. Issues of Economics No 2, p. 34.

20.Tax Code of Georgia (2017). Article 188, Tbilisi 2017. 